\title{
Is The World Enough? \\ Culture, Translation, and Impassable Differences in the Life of Victoria Ocampo
}

\author{
Marta Wilkinson \\ Wilmington College of Ohio
}

Our contemporary interest in globalization makes our world one in which it is commonplace that family members need a passport in order to visit one another and in which heritage language speakers are no longer the odd minority. This world is marked by transculturation and other incidences of overlapping ethnic and national heritages historically isolated for their "otherness" within a dominant socio-cultural structure seeking homogeneity to a white, western European ideology. In light of recent studies on intercultural maturity, this essay argues that Victoria Ocampo's relationship with language and culture can now be read as a blueprint for experiencing the modern world. These points converge in contemporary interest in cultural mediation as a necessary component in an idealized "global community."

The following discussion will elaborate several specific points in support of this interpretation of Ocampo's life as revealed through her Testimonios. These records of both experiences of, and reflections on, intercultural exchanges center on the dual processes of transculturation and translation as they affect the individual. In Ocampo's case, this is a reconciliation between European models and an American identity. Ocampo's relationship with language and her experience and practice of translation provide an example of the power and responsibility it carries in bridging cultures and navigating the differences between them.

Victoria Ocampo's education, which she acknowledges was much better than that of her female contemporaries, followed the models of western European domestic ideology of the previous century. As her reflections critique, "The average Argentine woman has only two callings: love and motherhood. A girl should be refined, but never educated"' (qtd. in Sarlo 121). ${ }^{1}$ The social position of her family allowed for the world, represented by other nations and languages, to be brought to her. Having the world brought into her home and receiving an education in French rather than in Spanish immediately confused the public/private binary in Ocampo's young life and thus her perceptions of intimacy with persons who, in her mind, embody the culture. The multiple volumes of her Testimonios bear witness to this relationship continuing throughout the rest of her life and become an integral part of her personal identification. She acknowledges in an early essay entitled "Palabras Francesas" ["French Words"] that her childhood memories would not even exist for her if not for the French

${ }^{1}$ All translations mine unless otherwise noted. 
language and thus, without that linguistic code and the cultural expression she understands as intrinsic to it, she would be denied an integral part of herself (Ocampo 30-32).

This relationship with language is part of a cycle that began with the stories she was given to appropriate as a child and extended into the written correspondence of her adult life. Language is created for her and consequently belongs to her. This confusion is evident in her reflections as she recalls the following:

Upon our return to Buenos Aires, my parents decided that the time had come to have me study English, since French was already conquered territory. I would return then to English soil months after having left it. England, this time, was called Miss Ellis. (Ocampo, Testimonios 1-5 78-79)

Ocampo perceives France and England as a part of her home and thus something which she can appropriate as her own; her own words describe them as territories to be conquered. Her feelings of returning to England with the arrival of Miss Ellis are renewed each time that she engages with the English language.

Language, text, and the author are one to her as she forms a fetishistic relationship with authors and characters who embody whole cultures for her, as she affirms: "I can say without exaggeration that Miss Ellis gave me Shakespeare and Milton, Byron and Shelley, Hazlitt and Jonson, Spencer and Chaucer, Keats and Dickens, the Brownings, the Brontës, Eliot and the two Lawrences, Shaw and finally, my dear friends, one of whom has so tragically died, Virginia Woolf and Aldous Huxley" (Ocampo, Testimonios 1-5 81-82). Victoria Ocampo invests in her readings the way one does in a dialogue, making her writing the most interpersonal relationship of her life. Without the medium of the text Ocampo would be isolated from those she knows and with whom she best identifies.

Culturally, Ocampo's upbringing relied wholly upon these imported European models. The foreign governesses were just one symptom of a continental lifestyle. Dress, table manners, and social relationship codes were all imported long before so as to be ingrained components of the cultural "norm" of Argentina in Ocampo's time. The sheltered life she lives is apparent in her shock and incomprehension of the coldness with which Europe greets her during her travels; the cultures which she has spent her whole life making her own are in fact not hers. Europeans still see Latin America as uncharted and uncivilized territory inhabited by primitive savages completely lacking in culture. Ocampo even found herself explaining to close friends such as Virginia Woolf that "the Argentine was not a great forest with alligators, butterflies as big as vultures, and natives pursued by pumas" (Bivar 2). For many of her European contemporaries she represents, in Doris Meyer's words, "not another continent but another world" (Wind \& Tide 104). 
Her experience however can be read within a larger cultural context as Kaminsky's studies on Argentina affirm that "Argentina both feeds and feeds off Europe's view of it, and Europe produces and consumes an Argentina that acts as a pivot between the exotic and the familiar" (Argentina xi). Ocampo initially does not recognize her positioning as such, but feels personally excluded by her European contemporaries as she seeks to embrace and be embraced by the cultures she understands as her own. Ocampo's early experiences clearly reflect the initial stages outlined in King and Baxter Magolda's model of intercultural development as Ocampo's responses attest her naïveté about different cultural practices and her dependency on "similar others" as a "primary source of identity and social affirmation" (576). This affirmation however was never accomplished.

The many volumes of Ocampo's testimonial writing illustrate her journey through language and culture; a journey through various stages of awareness, self-identification, and finally, the ability to "consciously shift perspectives and behaviors into an alternative cultural worldview" (King \& Baxter Magolda 576). Raised and educated by French and English governesses, French was her primary language of expression, making her social elitism a barrier between her, her fellow Argentines, and the rest of Spanish-speaking Latin America. This feeling is intensified by differences in the Spanish language itself which varies not only from the peninsula to the New World, but within the various countries of Latin America. When she began her publishing career as an adult, she continued to write in French and had her work translated into Spanish by Ricardo Baeza, and not without considerable conflict as her Latin American terminology engendered critical comments such as, "What barbarians!” (Ocampo, Testimonios 1-5 295). The choice reflected in the term "barbarians" highlights the cultural paradigm in which Argentina remains a wild New World territory represented by the pampas, rather than the modern nation Ocampo knows. Baeza's comment also stresses the lack of understanding between people who speak the same language much less those separated by history and geography.

One of the most significant of such experiences of cultural misunderstanding occurred during a period when the Indian poet Tagore stayed as a guest in her home. Ocampo may have been aware of the fact that Tagore arrived in South America with a prejudice: his own lack of popularity on the American continents instilled in him the idea that Americans are not capable of appreciating the delicacies of emotion that his poetry describes. Ocampo's translations of Baudelaire for Tagore lead to her first doubts of her knowledge of the English language and abilities to translate, and most importantly, to communicate.

As a guest in Ocampo's home, Tagore must have felt his privacy invaded upon occasionally, for example when she requests the translation of a poem that she only has access to by entering his room in her house. When she asks, "Why have you left out the part that is the marrow of the poem?' He replied that he thought that it could not be of interest to westerners. I felt the blood rise to my face as if I had been slapped" (qtd. in Sarlo 114-115). Bhattacharya's article, "Victoria Ocampo: The Exotic Muse in the Life of Rabindranath Tagore" offers a mediation that reveals what should have been obvious; that connections and similarities between nations and people exist around the world regardless of language. Tagore identified Latin America and 
Ocampo with the West, which is to say with Western Europe, rather than see the American continents as products of colonization. The colonized "other" of his own Indian nation was far more of a kindred spirit to the Latin American experience than he gave it credit for (62).

The linguistic challenges described above serve as metaphors for her life: Victoria Ocampo embodies the challenges of translation, both the power it carries to unite through communication, as well as the burdens of unresolved conflicts, cultural misunderstanding, and mistaken cultural identification. As evidenced by her writing, Ocampo's tendency to switch codes indiscriminately as she seeks out the expression that is most accurate to her observations was a practice long fossilized from her childhood. In "Palabras Francesas" Ocampo recounts an exemplary childhood experience in which one of her aunts asks her what name she would prefer to give to her newborn cousin. She writes:

I did not even stop to think: 'Geneviève.' I was then completely obsessed with this name. I read and re-read the story of Geneviève de Brabant, [...] My aunt took my hand and said to me: 'That name, in French, is certainly very pretty. But do you think that Genoveva is as nice in Spanish?' 'No,' I replied immediately. And, after a moment of bewilderment and doubt, I insisted: 'But why not name her Geneviève, in French?' My aunt began to laugh and shook her head: 'What we need is a Spanish name.' Disappointed, I could not think of anything to say. No Spanish name had the same aura as that one. My aunt continued, 'Do you remember that ugly servant that we used to have? Her name was Genoveva. You would not want your cousin to have that name.' To which I replied with indignation: 'I did not say Genoveva, but rather Geneviève. Geneviève, like Geneviève de Brabant.' (19-20)

Changing this form to the Spanish variant alters the sonority and beauty of the name. Ocampo recognizes the difference as a name change not merely a translation, as changing the language of the name changes the nature of the bearer. This type of re-naming is described much later in the testimonial writing of Richard Rodriguez who recalls his first day of school: "The nun said in a friendly but oddly impersonal voice, 'Boys and girls this is Richard Rodriguez.' (I heard her sound out Rich-heard Road-ree-guess.) It was the first time I had heard anyone name me in English" (9). His word choice, "name me," as if he does not already have a name and must be given one, is the clear mark of appropriation by the dominant culture. The new identity Rodriguez has to assume with the anglicized name establishes the division he later elaborates on as public and private language.

Culture and cultural identification are embedded in language. Richard Rodriguez is stripped of his Latino heritage with the name Richard just as Geneviève loses all of France in becoming Genoveva. This issue of naming that struck a chord in Ocampo as a child reflects her investment in a practice explored by Wittgenstein's Philosophical Investigations in which is stated that "to imagine a language means to imagine a form of life" (qtd. in Harpham 2). The form of life that the Argentine Ocampo knows is European. As such, her knowledge of language and studied knowledge of culture make her a cultural spy. To the Europeans she is an exotic outsider who 
has learned to adopt their languages and mannerisms in order to better dissimulate herself within their society as Kaminsky affirms:

In Europe Ocampo is a sophisticated woman, fashionable; she moves in a circle of artists, musicians, and writers. It is when she writes of Virginia Woolf that she lets us see how at least that one Englishwoman invents her as exotic. Ocampo writes [...] of Woolf's imaginary Argentina, a luxuriant and mysterious New World that Ocampo embodies for the British writer. (126)

As to appearances, Victoria can play the part of a European. Regarding personal identification, she cannot. Despite all appearances and education, Ocampo unknowingly identifies with the New World. In order to construct her own identity Ocampo enters into a dialogue with the various aspects of her life - a dialogue between her various "selves." She achieves communication between herself and the "other" by taking once again the world, represented by all its languages and cultures, as her object. This "other" that she communicates with is at the same time the Victoria Ocampo expressing herself in French and attempting to achieve clear communication with the one who speaks English, the one who speaks Spanish, and even the one who speaks Italian. By employing this method of the dialogic she appropriates all sides of allowing her to reclaim the experiences of her background and face the images of herself that others have constructed. Such reclaiming allows her to understand the differences in expression that linguistic difference perpetuates and the reasons behind the cultural misunderstandings that plagued her life and career.

This reclaiming allows her to complete an essential step along the road to intercultural maturity-knowing the self. Experiences with Tagore and even extensive exchanges with others such as Virginia Woolf remind Victoria of this "otherness" and the need to define an identity of her own. It is interesting to see that others have fetishized her much as she has language. Regardless of her skills she is still always seen as a rich woman, an attractive woman, and a Latin American.

Because of Ocampo's wide-reaching connections, Kaminsky's Argentina: Stories for a Nation asserts that she "must be acknowledged as a pivotal figure in the construction of Argentina in the global imaginary" (70). Kaminsky discusses the complex relationship between Europe and Argentina and the imbalance therein as follows: "For Europe Argentina is just one of its many mirrors, [...] For Argentina, its very meaning has depended on its reflection in the eyes of its others" (32). In terms of globalization, the image that exists in the eyes of others, a simple exercise of projection, may be the only validation available. It is easy to ignore the "people," since references to "nation" dominate as Hardt and Negri's "concept of the multitude" implies (Beverley 8).

Elizabeth Marchant describes Ocampo's approach to writing as reflecting a belief that "one's 'self is always inextricable from one's 'object' of study" (48). Ocampo's self is inextricable from the experiences which made translation a way of life. Decades of living between cultures and languages were necessary for Ocampo's journey to her "self" to be complete. Her time and 
circumstances were distinctly unique. Life in the new millennium provides an increased likelihood that one's self is forced to live in a place and culture far removed from one's neighbor's or familial roots. Rather than a select few marked by difference, difference is pervasive. In the struggle to understand the how and why of "others," the need to acknowledge the self remains central. In order to achieve a global community, all citizens will need an "understanding of cultural differences (cognitive dimension), [a] capacity to accept and not feel threatened by cultural differences (intrapersonal dimension), and [a] capacity to function interdependently with divers others (interpersonal dimension)" (King \& Baxter Magolda 574).

Ocampo eventually opens herself up to accept the exoticism that others associate with Latin America and achieves the interpersonal dimension of intercultural maturity by shifting perspectives and adapting "multiple cultural frames" (King \& Magolda 576). Ocampo demonstrates a clear understanding of cultural difference in her ability to dissimulate herself within multiple cultural contexts while accepting her own American identity. That acceptance allows her to surrender her experiences of offense repeated through years of cultural misunderstandings. This intrapersonal maturity is demonstrated in her work as Kaminsky describes how Ocampo takes it upon herself to be not just a cog, or even a "máquina cultural" as Sarlo describes (280), but a cultural architect ("Essay" 118). This marks an interesting reversal to the construction that took place with her own education. Her social position and her education constructed her and therefore she was not able to function completely in any of the pre-existing spaces the world had to offer. Rather than submit to a role and to a place in which she would try to disguise her "otherness," or let such alienation consume her, she constructs another space above and beyond pre-existing cultures. Within that space she is able to seize texts, ranging from Baudelaire and Lawrence to Gandhi, and allow her own understanding and experience to infuse the translated page. Her space is that of mediation; mediation and interpersonal maturity both taking place in the process of translation. This process too is highly personal and parallels her life-long experience as one of the many other translators who worked for Ocampo, Enrique Pezzoni, expresses his belief that "everyone is a translator, and offers a potential commentary upon the limits of translatable space by including all of the real and imaginary spaces one inhabits, past, present and future" (Larkosh 64). Thus Ocampo's experience with language as conquered territory, imported domestic ideology, and cultural misunderstanding inform her work as a translator and her goals as a publisher.

For Victoria Ocampo translation is not so much a process as a way of life. For someone raised in a polyglot environment the facility of moving between languages in order to find the best possible expression is a natural function. As described by Beatrice Sarlo, "...foreign language was not learned, it was absorbed from teachers or books as if by osmosis. [...] Foreign language surrounded these girls like an atmosphere and was breathed in as if it were air" (119). The "fluidity between identities" that Elizabeth Marchant presents implies the divided presence of various cultural identities, each personified in its representative language (49).

Ocampo's practice of transcribing texts in various languages, recounting conversations with foreigners, and describing foreign locales by employing various foreign languages 
indiscriminately clearly illustrates her desire to find the best possible form of expression at her disposition. Selecting the best method of expression affirms her practice of negotiating the cultures that have formed the languages. Such a negotiation is also one which a monolingual mind, or even the mind of someone who learns a second language later in life, cannot understand.

For the person who learns a second language later, that language will always be marked by difference - will always be the "other" language. For a person who is truly bilingual (or trilingual), language is language; it is pure expression without the divisions imposed by national and linguistic difference. George Steiner presents a reflection of such an employment of language in After Babel, describing the phenomenon embodied by Ocampo:

The bilingual person does not 'see the difficulties', the frontier between the two languages is not sharp enough in his mind. [...] If this is true, it suggests that a bi- or trilingual individual does not proceed laterally when translating. The polyglot mind undercuts the lines of division between languages by reaching inward to the symbiotic core. In a genuinely multilingual matrix, the motion of spirit performed in the act of alternate choice-or translation-is parabolic rather than horizontal. (124-125)

In this parabola of languages and cultures there is constant and cyclical motion. Ocampo instinctively understands that the role of language is not to concern itself with the void in the parabola, but with the completion of the arc that arrives nonetheless at its meaning. This parabola arrives at that target meaning without recourse to questions of culture, linguistic difference or gender. These are all items that exist in the periphery and which obscure meaning rather than clarify it. As Ocampo struggles to complete the parabola of translation that conveys meaning, the world of horizontal thinkers constantly hinders her work by interjecting these other issues which she is forced to face in order to continue her life's vocation.

Ocampo truly validates and empowers herself in the translation process as she faces the dilemma that plagued her since childhood: are there elements that cannot be translated because perhaps they should not be? I suggest that Ocampo found the most intimate elements of cultural integrity in those untranslatable passages. Trying to force a translation upon the untranslatable violates not only the language but the culture, and the history that has made both what they are.

Ocampo's realization that not everything can be translated illustrates the theoretical viewpoints expressed in Lecercle's Philosophy through the Looking Glass describing language as "an unconscious machine ... It produces both concrete utterances and the subjects who utter them. Our discourse is produced by a machine. We are part of its arrangement... We do not use language as a tool, but are just a few of its innumerable cogs" (187). Lecercle attributes agency to language and acknowledges that changes carry deeper investment than a mere substitution of symbols and signs. Geoffrey Harpham's work Language Alone: The Critical Fetish of Modernity clarifies this argument by explaining that when agency is granted to language, language itself absorbs "a good part of the responsibility for our shortcomings" (48). The appropriation of culture or the re-naming of individuals is then not a brutal and violent theft of identity and 
cultural heritage, but the fault of language, as we need words that fit into the same code in order to make ourselves understood. From Ocampo's perspective however, these areas of misunderstanding or miscommunication are not the fault of language, but rather the fault of mankind as she describes in her essay, "Babel," her own version of the biblical tale:

It is very probable that the punishment He inflicted was more refined, more cruel. It must have been as follows: Jehovah didn't alter the words of Noah's children, but rather He changed the perception that each of their brains had of those words. The words continued being externally as they had been until then, but internally they became something different for each man. The words, then, continued sounding like they always had, but their resonance was distinct in each ear. (121)

The inevitable isolation of the individual in such a world forces Ocampo to turn inward to find a resolution between the self constructed by her polyglot method of expression and the various social arenas she interacts in. In "Palabras Francesas" she acknowledges that a separation from the French language would mean a separation from her self, a separation from her childhood and all of the memories of the stories and games that made her experience what it was, and her who she is now. With "Babel" she accepts her isolation and acknowledges that language is only a part of the problem. She also learns to accept others whose experience of language is not like hers and realizes that her belief that culture translates itself along with language has only led to disappointment. While culture is embedded in language, it is not necessarily understood by others who are removed from that culture or who try to understand a meaning that has undergone the transformation from one linguistic styling into another. The similarities between persons of differing national histories and the possibility of explaining the cultural differences to one another is something that often remains unfulfilled in Ocampo's relationships. These areas of misunderstanding, or miscommunication, are more the result of the faults of mankind as mentioned in "Babel" than of a fault of language. Experiences with Tagore and even extensive correspondences with friends such as Woolf remind Ocampo of her "otherness" and the need to define an identity of her own.

Ocampo's relationships with others, so long characterized by distance, are revealed to also have been mistakes of perception of distance. Initially, she herself only saw those relationships in this way as well: "I have always seen the Atlantic as a symbol of distance. It has always separated me from beloved beings and things. If it wasn't Europe that I longed for, then it was America" (Ocampo, "Woman" 126). She learns to assign new value to her objects and rather than resent the space created by the oceans, eventually learns to respect and to navigate them. She learns distances and limitations as well as the most direct and safe passages and even declares a hope that "[p]erhaps someday we will make them into beautiful, fast, safe, highways" (126-127). What eventually become invaluable are not the destinations she once longed for as much as the passages in between. It is in between nations, or above language, that translation, and thus mediation takes place.

Rather than seek some homogenous standard for a global community, difference must be embraced, negotiated, and accepted as Ocampo demonstrates through her experience. This 
acceptance lies in those passages that she deemed simply untranslatable. The untranslatable is like the oceans that separate continents. They are passages whose vastness cannot be surmised, are both beautiful and dangerous, and above all, must always be respected. Ocampo learned a profound respect for the untranslatable, going so far as to elevate translation to a moral question in her essay "Moral y literatura" ["Morality and Literature"]:

That part of an author's work that does not pass from one language into another is precisely a sign of its excellence; it is the result of an encounter between the genius of the author and the genius of a language. As such, beautiful prose and beautiful verse have no better translation than equivalencies; equivalencies that at times stray from the text in order to remain faithful. That is why there do not exist worthy translators outside of persons who are writers themselves. [...] However, even though the expression of thoughts and feelings has been achieved, it will never be exactly the same, as a violin melody played on a flute or a harp changes in sonority. It may have gained or lost in beauty, yet in both cases it will be different. Such is the power of the word. (Ocampo, Testimonios 1-5 88-89)

While everything cannot be translated, it can be explained. It is in the explanation that the translator becomes mediator. In discussing the moral responsibility of translation in regards to cultural history, Steiner in After Babel asserts that in many situations " $\mathrm{t}$ ] here are mysteries which can be transcribed, which it would be sacrilegious and radically inaccurate to transpose or paraphrase. In such cases it is best to preserve the incomprehensible" (262). The mediation of cultures necessary for a global community is achieved in the selective interpretation that is essential to the translator's task.

Hermann Keyserling is quoted to have said that, "Victoria truly belongs more to the world than to Argentina" (qtd. in Meyer, "Myths" 86). This author suggests that Ocampo made the world hers and that this possession came over time and at the price of many painful lessons. The labyrinth of the world's languages and cultures continued to prove itself the "Babel" of her own interpretation. Ocampo learned to go beyond the people, beyond the borders, and beyond the binaries. It is only in neutral territory that mediation can take place; a territory neutral, yet one in which we are all united "by a common human condition" (Ocampo, Testimonios 67). From that first realization that "Genoveva" could never be "Geneviève," she traveled on to explore infinite dialogues on multiple continents, only to finally realize that in order to attain a global understanding of the various cultures that mankind has created, perhaps this world is not enough. 


\section{REFERENCES}

Beverley, John. Testimonio: On the Politics of Truth. Minneapolis: U of Minnesota P, 2004. Bhattacharya, Malabika. "Victoria Ocampo: The Exotic Muse in the Life of Rabindranath Tagore." Victoria Ocampo: An Exercise in Indo-Argentine Relationship. Ed. Embassy of Argentina in India and Susnigdha Dey Delhi: B.R. Publishing, 1992. 55-74.

Bivar, Antonio. "As If Virginia Woolf Were a Great Brazilian Writer..." Virginia Woolf Miscellany. 54 (Fall 1999): 2.

Harpham, Goeffrey Galt. Language Alone: The Critical Fetish of Modernity. New York: Routledge, 2002.

Kaminsky, Amy. Argentina: Stories for a Nation. Minneapolis: U of Minnesota P, 2008.

— . "Essay, Gender, and Mestizaje: Victoria Ocampo and Gabriela Mistral." The Politics of the Essay. Ed. Ruth-Ellen Boetcher Joeres and Elizabeth Mittman. Bloomington: Indiana UP, 1993. 113-30.

King, Patricia M. and Marcia B. Baxter Magolda. "A Developmental Model of Intercultural Maturity.” Journal of College Student Development. 46.4 (2005): 571-92.

Larkosh, Christopher. "The Translator's Closet: Editing Sexualities in Argentine Literary Culture." TTR. XXI.2 (2007): 63-88.

Lecercle, Jean-Jacques. Philosophy through the Looking-Glass: Language, nonsense, desire. London: Hutchinson, 1985.

Marchant, Elizabeth A. Critical Acts: Latin American Women and Cultural Criticism. Gainesville: UP of Florida, 1999. Meyer, Doris. "The Multiple Myths of Victoria Ocampo.” Revista/Review Interamericana XII.3 (1982): 385-92.

- Victoria Ocampo: Against the Wind and the Tide. New York: George Braziller, 1979. Ocampo, Victoria. "Babel." 1931. Trans. by Doris Meyer. Rereading the Spanish American Essay: Translations of 19th and 20th Century Women's Essays. Austin: U of Texas P, 1995. 121-25.

—_ "Palabras Francesas." Testimonios. 1931. Madrid: Revista de Occidente, 1935. 19-41. Testimonios: Series primera a quinta. 1931-1957. Ed. Eduardo Paz Leston. Buenos Aires: Editorial Sudamericana, 1999.

—_ "Woman and Her Expression." Trans. Patricia Owen Steiner. Rereading the Spanish American Essay: Translations of 19th and 20th Century Women's Essays. Ed. Doris Meyer. Austin: U of Texas P, 1995. 126-34.

Rodriguez, Richard. "Aria.” Hunger of Memory. New York: The Dial Press, 2005. 7-27.

Sarlo, Beatriz. La maquina cultural: Maestras, traductores, y vanguardistas. Buenos Aires: Ariel, 1998.

Steiner, George. After Babel: Aspects of Language and Translation. 2nd ed. Oxford: Oxford UP, 1992. 